\title{
Stanley and me
}

Cite as: CMAJ 2018 May 28;190:E658-9. doi: 10.1503/cmaj.180219

CMAJ Podcasts: audio reading at https://soundcloud.com/cmajpodcasts/180219-enc

tanley ambled into the interview room for his 3 o'clock appointment, sliding the box of smokes back into his pocket and looking across at me expectantly. As usual, he kept his jacket on, not fully settling into the office chair.

Paranoid schizophrenia had aged him. Many of his nearly 60 years had not been kind, although his dark, line-rimmed eyes remained so.

He had survived decades of institutionalization, having been told at one point wrongly, as it turned out - that he would never again live on his own. He was determined to continue to prove those doctors wrong. The haunting delusions and fearful hallucinations had long ago left him, and although he had a periodic feeling of confusion, and his memory gave him some trouble, he was able to live independently with the help of Meals on Wheels and his outreach worker. He led a solitary and simple existence, anchored around his careful, even obsessive routines. If his pills arrived slightly late, or his online bank balances (checked many times daily) did not reconcile to the penny, he was highly unsettled, and much of his time was occupied in managing the repetitive details of his life. Nonetheless, he was content.

Much later, when he began to have dizzy spells and falls, and had trouble managing his medications, he clung fiercely to his little apartment, and any talk of supported housing would meet with a prickliness he otherwise rarely displayed. I failed to grasp, at the time, how much he feared any move that might foreshadow institutional life closing around him again.

I had been seeing Stan periodically for several years, supplementing his visits to his family doctor. He usually arrived early, Tim Hortons coffee in hand, his wiry frame slightly bent, putty-coloured cap pulled low over his forehead. His words

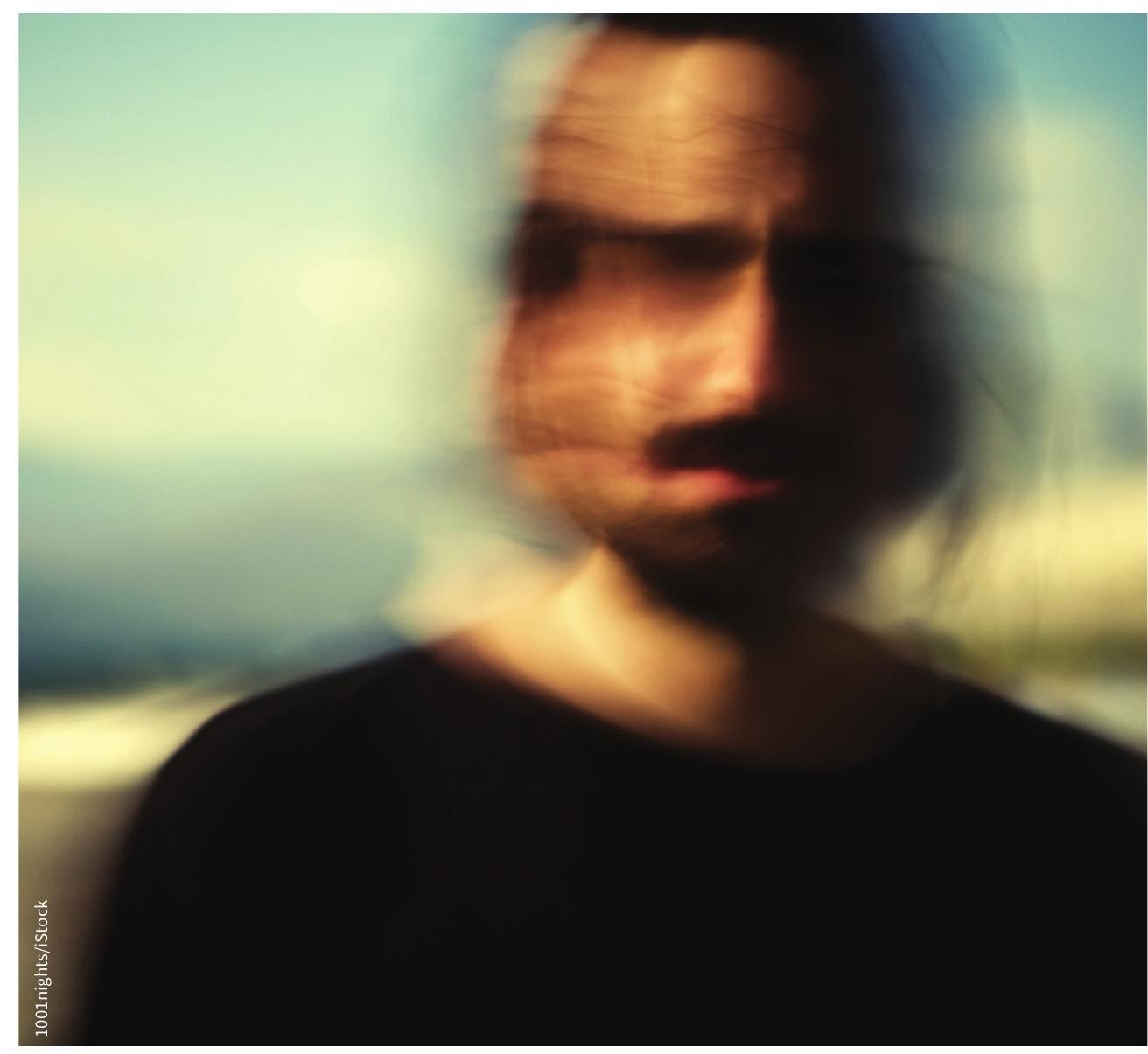

were deliberate, emphatic, his mildly nasal voice edged with cigarette-smoke huskiness and somewhat garbled owing to his dislike of dentures. The hint of tardive dyskinesia from years of older antipsychotic medications was barely noticeable: a subtle flickering around the mouth, easily mistaken for nervousness or fleeting emotion. He wasn't too interested in switching over to newer medications, and would furrow his brow warily at the suggestion of any change. But he was happy to talk to me about his favourite TV shows, the foods he enjoyed, the latest happenings in his building. Unlike some others who had long endured this same disease, his emotions were not flattened, his sense of humour still sharp.

Stan's main objective in life was to stay out of hospital. I had almost forgotten how reluctant he was at first to see me, fearful that psychiatrists always wanted to "put you away."

This day, just before leaving, he unexpectedly asked me if I remembered an article I had written some time before, a piece in our community mental health newsletter in which I outlined the anatomy of a psychiatric assessment - what to expect when seeing the "shrink." 
"I always read it before I come here. Every time," Stan said solemnly.

Startled, I looked at him more closely.

"Are you nervous before your appointments with me, Stan?"

"Not nervous, exactly. Just ... cautious." He didn't quite meet my eyes. "I've had some bad experiences with psychiatrists."

I nodded, and felt a shift of perspective click into place. I had come to view our infrequent check-ins as a welcome and relaxing change from the often intense, sometimes crisis-ridden encounters with my more acutely ill clientele. Stan could not afford to view them quite as sanguinely, each visit a reminder of the potential fragility of his hard-won independence. I nodded again. This time his eyes met mine.

He hesitated momentarily, then blurted: "If I brought it in, would you sign it? Would you autograph it for me?"

I blinked. My throat tightened slightly.

"Uh ... absolutely. Of course I would. of course," I repeated, a little too vigorously.

Absolutely, Stan.
It feels like some kind of contract between us, this thing he is requesting. A formalizing of the unspoken contract already in place:

He will show up, reveal himself to me.

I will treat him respectfully.

He will trust me.

I will deal honestly with him.

He will risk venturing far from his hard-won sanctuary, even knowing that I am a part of that system which once confined him.

I will tread gently and with compassion, as I enter his places of vulnerability.

All of this unarticulated, played out in simple gestures.

A repeated dismantling of fear.

I think of my own fears - of inadequacy, of mistakes - that at times accompany me to the office. On those days I arrive tired, or apprehensive, I am sometimes aware of an invisible cloak that has replaced the white coat of my training: a mantle of responsibility, one that I can almost feel sliding over my shoulders as I prepare for my first patient. My credentials, my experience, my role, even the grey hairs at my temples, provide a certain authority - not, I hope, of the paternalistic or authoritarian sort, but something invested in our profession through its long history: a gravitas that transcends me as an individual and invites confidence and trust. It has the potential to lend power to the healing encounter. I had forgotten that it could also be experienced as a threat.

Stan had not.

Rising to his feet, he nodded gravely, pulled his cap down and abruptly walked out of the office, away from the perilous world of doctors and questions. His narrow chin jutted forward with determination as he escaped back into the open space of the parking lot, squinting slightly at the unexpected brilliance of the waiting sunlight.

\section{Beverly J. Goodwin MD}

Lanark County Mental Health, Smiths Falls, Ont.

This article has been peer reviewed.

This is a true story, although it happened long ago. Stanley is not the patient's real name. 